\section{Tolerable Pollution}

SIR,- I have read with great interest Dr Samuel S. Epstein's article entitled "Control of Chemical Pollutants" (Nature, 228, 816; 1970). Many of the points made by Dr Epstein are very well taken and need emphasis. Unfortunately, however, some of the concepts that he expresses need to be examined more closely and carefully thought through.

For instance, in the determination of "efficacy" the practising physician may have entirely different concepts than the academician who is not dealing with patients on a daily basis. To the academician there is probably no place for a placebo. To the harassed physician trying to bring solace to the whining, complaining patient the placebo may have a most important, though limited, role. I remember clearly a female patient I once had of $70+$ years who demanded of me a "tonic". "Tonics," it should be remembered, were practically a part of the culture of people in this age range. Finding no "tonics" in the formulary of the hospital where I was working, I prescribed an innocuous "bladder mixture" made up of potassium iodide and hyoscyamus. Much to my surprise, the patient returned at her next visit lauding the "efficacy" of this "tonic" to the skies and insisted that it be renewed. Obviously this was not a material that $l$ should be permitted to market as "Dr E's famous tonic", but was there any harm in its use in these circumstances? Who, then, is to determine efficacy? Should flavours, colours, antirancidity materials or other such materials be permitted in foods? Do they have "efficacy"? Some might well argue that foods should be eaten only with their natural inherent flavours and colours and that the addition of artificial (or even natural) flavours or colours does not improve the food's efficacy. Rancid food should simply be thrown out. What about the present uproar over the use of tolbutamide in diabetics? Even cyclamates are thought by many physicians to have value in the treatment of obesity and diabetes. Who is to make these important determinations?

Turning to the concepts of carcinogenicity, teratogenicity, and mutagenicity, there are few people who do not believe that we should control them to the best of our ability. However, as I pointed out in my Ramazzini oration (J. Occ. Med., 13, 161; 1971), the concept of zero is a mathematical one. As our analytic techniques become more and more sensitive, it will ultimately be necessary for us to establish a "practical" zero. In essence this will mean that some finite, measurable quantity will be determined to be "tolerable". Thus a "tolerance" for carcinogens, teratogens, and mutagens will be established. Precedence for this approach has been established in the milk and water sanitation fields. Here a definite number of organisms are allowed, that is, are considered tolerable. It was recognized that to set the levels at zero organisms could well have eliminated these essentials from human consumption. Thus recognizing the impracticality of the so-called Delaney clause and devoting research efforts to a serious attempt to establish tolerances for carcinogens seems a more sensible approach than simply extending this concept to teratogens and mutagens. This approach has been taken by Truhaut and an international committee in attempting to establish a tolerance for aflatoxins in foods.

Lastly, the concept of "disinterested" scientists needs carefully to be examined. What, truly, do we mean by a "disinterested" scientist? Is he "disinterested" because he is an academician?
After all, Pasteur made what is probably one of the most important discoveries to mankind when he was working for the French wine industry. Is the scientist directly engaged in or dependent for support from a federal bureaucracy "disinterested" in its perpetuation? Can a scientist's views be modified as he lives longer and becomes more mature and knowledgeable? Is this change in viewpoint due to his having lost his disinterested status?

The concepts I expressed in my editorial on environmental carcinogenesis (Cancer Res., 22, 395; 1962) seem today to need re-emphasis. We do need to control significant exposures of the general population to carcinogens, teratogens, and mutagens. After all, today we do not have any real comprehension of what the teratogenic or mutagenic rates are in the human race as a whole. For all we know, these rates may be on the downswing now because of man's ability to overcome some of the vicissitudes of his former existence. A rereading of the "Report on the Sanitary Condition of the Labouring Population of Great Britain" by Edwin Chadwick, 1842 (edit. by M. W. Flinn, Edinburgh University Press, 1965) should reassure us on the real progress we have made in just a little over 100 years. We still, nonetheless, live in a real world, fraught with real and imminent dangers which we must do our best to minimize in a real and practical way.

Yours faithfully,

\section{R. E. ECKARDT}

Director

Esso Research and

Engineering Company,

Medical Research Division,

PO Box 45,

Linden, New Jersey 07036

\section{Obituary}

\section{Wendell Meredith Stanley}

Wendell. Meredith Stanley, Professor of Molecular Biology and of Biochemistry at the University of California, Berkeley, died suddenly, aged 66 , on June 15 in Spain.

His career in biochemistry and molecular biology began at the University of Illinois in 1926 when, as a graduate student of the organic chemist, Roger Adams, he synthesized a series of fatty acids and correlated their structures and physical properties with effectiveness against the leprosy bacillus. After earning his $\mathrm{PhD}$ degree in 1929, Stanley went to Germany as a National Research Council Fellow in the laboratory of Professor Heinrich Wieland, where he worked on sterols of yeast. Returning to the United States in 1931, he worked for a year at the Rockefeller Institute for Medical Research in New York with cell physiologist W. J. V. Osterhout, on model chemical systems that simulated cell membranes.

In 1932, Stanley moved to the Rockefeller Institute Laboratories in Princeton, New Jersey. There he began his studies on the chemistry of viruses which culminated in 1935 with the crystallization of tobacco mosaic virus
(TMV), the first of these disease agents to be obtained in such a form. Not content with the isolation and crystallization of TMV, he proceeded with a small group of colleagues to develop systematically and imaginatively an entirely new field of science: the biology, chemistry, and physics of viruses. From these efforts, and work elsewhere. the chemical composition and morphology of a variety of viruses were defined in molecular terms. Stanley's initial studies on the chemical modification of viruses later provided the foundation for inactivating viruses for vaccine production and for studies on molecular 


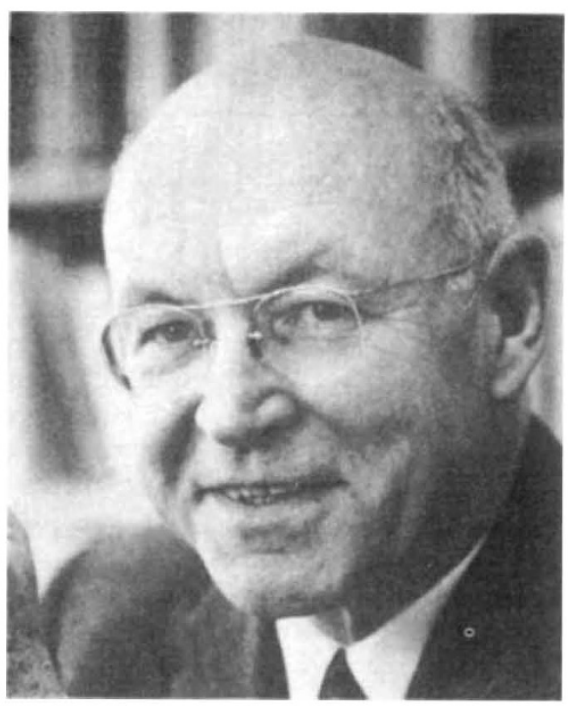

genetics. With the onset of the Second World War, his group turned to animal viruses and their fundamental studies on the purification and characterization of influenza virus led to the preparation of a safe and effective vaccine.

Stanley joined the University of California at Berkeley where, in 1948, he founded the Virus Laboratory and built a new Department of Biochemistry which he served as Chairman until 1953. Subsequently he initiated the formation of the Department of Virology in 1958 which he chaired until 1964 when it was expanded to become the present Department of Molecular Biology. In these academic departments, Stanley promoted and fostered the blending of teaching and research in a most fruitful way. His own interests were directed toward the conquest of viral diseases and the potentialities of viruses in the induction of cancer. $\mathrm{He}$ encouraged research in this area and exerted considerable influence in programmes on the national level. His contributions to cancer research were recognized by two awards from the American Cancer Society, one in 1959 and another in 1963 and by his selection as President of the Tenth International Cancer Congress, Houston, Texas, in 1970.

Many honours came to Stanley over the years: elections to honorary societies, distinguished lectureships, about a score of honorary degrees, and numerous medals and prizes including the Nobel Prize in Chemistry in 1946. In his lifetime, he had three different and equally productive careers: first as a bold, imaginative scientist whose research revolutionized biological thought; second as an outstanding educational administrator who recruited, supported and inspired many young scientists; and third as a distinguished statesman who played a major role in shaping enlightened national and international policy with regard to scientific research on cancer and the role of viruses.

\section{British Diary}

\section{Monday, September 13}

Fundamentals of Software for Computer Engineers (vacation school, thirteen days) Institution of Electrical Engineers, in association with the Institution of Electronic and Radio Engineers, at the University of Manchester.

Surface Chemistry of Oxides (three-day Discussion) Faraday Society, in the Chemistry Department, Brunel University, Uxbridge, Middlesex.

\section{Tuesday, September 14}

5th Annual Solid State Devices Conference (three days) Institute of Physics and the Physical Society, in collaboration with the Institution of Electrical Engineers, the Institution of Electronic and Radio Engineers, the Institute of Electrical and Electronic Engineers, at the University of Lancaster.
Flexographic Printing Inks (7.30 p.m.) Oil and Colour Chemists' Association, at the Griffin Hotel, Boar Lane, Leeds.

\section{Wednesday, September 15}

Centrifugal Methods of Particle Size Analysis (2.30 p.m.) Society for Analytical Chemistry, North East Section and the Particle Size Analysis Group, at Newcastle University, Room L.101, Mertz Court, Queen Victoria Road, Newcastle-upon-Tyne.

Formulation of Two Epoxy Paints (4.30 p.m.) Mr A. McWilliam, Oil and Colour Chemists' Association, at the Manchester Literary and Philosophical Society, 36 George Street, Manchester 1. (Student Lecture.)

\section{Thursday, September 16}

Insect/Plant Relationships (two-day symposium) Royal Entomological Society of London, at the Imperial College of
Science Mechanical Engineering Lecture Theatre, Exhibition Road, London SW7.

Modern Analytical Techniques for BioActive Substances (two-day meeting) Society for Analytical Chemistry, at the University of Surrey, Guildford, Surrey.

\section{Friday, September 17}

The Work of the Government Chemist (7 p.m.) Dr H. Egan, Society for Analytical Chemistry, Western Region, in the Chemistry Department, University of Bristol.

\section{Sunday, September 19}

Electrical Measurement Practice (vacation school, thirteen days) Institution of Electrical Engineers, in association with the Institution of Electronic and Radio Engineers, at the University of York.

\section{HOW TO BUY NATURE}

Volumes start in January, March, May, July, Septembe and November, but subscriptions may begin at any time.

The direct postal price per subscription is :

12 MONTHS* (52 issues per title)

\begin{tabular}{|c|c|c|c|}
\hline & & & ight \\
\hline & worldwide & U.S.A. & Canada \\
\hline Nature (Friday) & E14 & $\$ 48$ & $\$ 52$ \\
\hline $\begin{array}{l}\text { Neture }+ \\
\text { Nature Physical Science }\end{array}$ & $£ 24$ & $\$ 83$ & $\$ 90$ \\
\hline $\begin{array}{l}\text { Nature }+ \\
\text { Nature New Biology }\end{array}$ & E24 & $\$ 83$ & $\$ 90$ \\
\hline All three editions & $£ 29.50$ & $\$ 108$ & $\$ 116$ \\
\hline Annual Index & £1 & $\$ 3$ & $\$ 3$ \\
\hline
\end{tabular}

- Rates for shorter periods pro rata (minimum three months) (Charge for delivery by air mail on application)

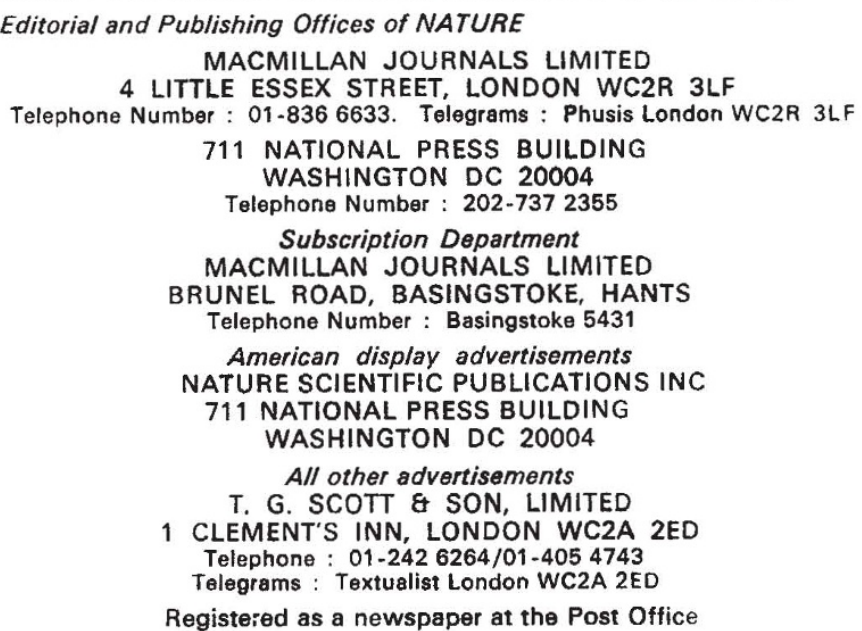

